\title{
DIE RING
}

\section{In diens van onderlinge sorg}

\author{
ABSTRACT \\ THE CLASSIS. IN SERVICE OF MUTUAL CONCERN
}

Congregations of the Dutch Reformed Church in South Africa are facing various challenges which they cannot meet on their own. The classis or presbytery was born in the sixteenth century when reformed congregations also went through very difficult times. Its aim was to help congregations fulfil their needs. Neighbouring congregations that are close enough to understand each other's needs and able to meet as often as needed, constitute this governing body. It has its roots in the sense of unity and concern that existed between the congregations of the first century. Throughout the history of the classis in the Dutch Reformed Church in South Africa, this same sense of unity and concern about the welfare of the congregations constituted the presbytery. Today it is still an integral part of the church's organization and can help congregations to fulfil their God-given calling in their own context.

\section{INLEIDING}

Die ring ${ }^{1}$ word in gereformeerde kringe beskou as die hartaar van die meerdere vergaderings van gereformeerde kerke (Kleynhans 1973:217; Spoelstra 1989:248). Dit is immers die eerste uitdrukking van kerkverband en

1 In sommige gereformeerde kerke staan hierdie meerdere vergadering bekend as 'n klassis, soos die Sinode van Emden 1572 dit genoem het (Biesterveld \& Kuyper 1905:36). Hierdie naam het moontlik sy oorsprong by die naam van 'n predikantevergadering in die gereformeerde kerke in Frankryk (Bouwman 1934:126). Die term klassis het in sy betekenisveld begrippe soos byeenroep, 'n versamelde menigte en corpus (Bouwman 1934:126). Die Algemene Reglement van 1816 het naas die klassis ook voorsiening gemaak vir 'n kerklike byeenkoms wat 'n ring genoem is (Artikels 49, 78-83 in Pont 1991:36,40). Dit was 'n predikantebyeenkoms wat deur die klassis gereël is met onderlinge ondersteuning as doel. Die eerste Algemene Kerkvergadering of Sinode van die Kaapse gemeentes het die term ring gebruik vir die meerdere vergadering wat tot dan die

Dr. A. Celliers Navorsingsgenoot: Departement Ekklesiologie, UV. E-pos: bertus9@mtnloaded.co.za.

Acta Theologica

$201131(2): 1-23$

doi: http://dx.doi.org/10.4314/actat.v31i2.1

ISSN 1015-8758

(C) UVIUFS

<http://www.uovs.ac.za/ActaTheologica> 
'n vergadering van gemeentes wat naby genoeg aan mekaar is om mekaar se omstandighede te verstaan en mekaar werklik by te staan en te help ${ }^{2}$. Hierdie kerklike vergadering is in die sestiende eeu in die lewe geroep vanweë die bedieningsnood van gemeentes. Dit het sy wortels in die eenheidsbewussyn en onderlinge besorgdheid wat tussen die gemeentes van die eerste eeu na Christus geleef het. In beide tydperke was die kerk in 'n soort storm vasgevang (Sweet 2007:18).

Daar is teoloë wat oortuig is dat die kerk tans die perfekte storm trotseer, en dat sy sal moet swem of sink (Niemandt 2007:11; Sweet 2007:17evv). Postmodernisme, postchristendom en globalisering is die drie oorheersende faktore wat die wêreld waarin die kerk lewe onherroeplik verander. Dit stel enorme uitdagings aan die kerk. Niks, so word beweer, sal ooit weer dieselfde wees nie. Die situasie word vergelyk met die Renaissance en hervorming van die vyftiende en sestiende eeu. Dit bring geweldige onsekerhede en spanning vir die kerk in sy geheel, maar ook vir gemeentes (Niemandt 2007:12ev). Intussen, of dalk as gevolg van die winde van verandering, staar 'n hele aantal uitdagings gemeentes in die gesig. Uitdagings wat gemeentes blykbaar toenemend op hulle eie probeer hanteer.

"ledere een is besig om op sy eie manier aan te neuk" is die opskrif van die rubriek, Anton Pienaar op die kerk se trappe in die Kerkbode van 1 Oktober 2010 (Pienaar 2010:8). Hy maak gewag van 'n groeiende individualisme onder predikante en gemeentes. In die wandelgange word selfs van "kompetisie" tussen gemeentes binne dieselfde ring gepraat (vgl. Strauss 2010:66). Buurgemeentes ding met mekaar mee om die grootste "markaandeel" uit die beskikbare "kliënte" in die omgewing te verkry (Sweet 2007:55; vgl. Pienaar 2010:8). Dit terwyl die nood onder gereformeerde susterskerke hoog is. ' $n$ Krimpende lidmaattal en gemeentes wat stoei om te oorleef, is op alle sinodes se agendas. Kerkrade wat sukkel om vakante kerkraadsposte te vul, is lankal ou nuus. Diverse aanbiddingsstyle en liturgiese inkleding tussen gemeentes, dieperliggende verskille oor die belydenisskrifte en hulle inhoud, verskillende Skrifbeskouings, kerkbegrippe en standpunte oor sake soos homoseksualiteit, die huwelik, die doop en die Belydenis van Belhar dui op 'n krisis in die kerke van gereformeerde oorsprong hier te lande (vgl. Diversiteitsforum s.a.).

klassis genoem is (Algemene Reglement 1824 artikel 1 in Pont 1991:216), soos wat dit vandag nog in die Nederduitse Gereformeerde Kerk genoem word.

2 Gemeentes is volledig kerk omdat die merktekens van die ware kerk, naamlik die suiwer bediening van die Woord, die sakramente en die kerklike tug (Nederlandse Geloofsbelydenis artikel 29) slegs daar kan voorkom. Gemeentes is dus struktureel gelykwaardig (Strauss 2010:51). 'n Ring wat gesond funksioneer maak wel nie die gemeente as volledige kerk meer kerk nie, maar dit dien "tot nut en versterking van die gemeentes" (Strauss 2010:65). Heyns (1977:174) praat in hierdie verband van die kerkverband wat gemeentes help om beter kerk te wees. 
Dat ringe as gevolg hiervan ook in 'n krisis is, staan nie te betwyfel nie. Op 'n byeenkoms van die Kerkregwerksgemeenskap van Suid-Afrika in September 2011 is drie referate bespreek wat gehandel het oor die krisis van ringe in onderskeidelik die Protestantse Kerke in Nederland, die Nederduitse Gereformeerde Kerk (Suid-Afrika) en die Verenigende Gereformeerde Kerk (Suid-Afrika). In baie gevalle het die ring verval tot bloot 'n verslag-enkennisname vergadering (vgl. Coertzen 1984:6, 34, 36, 39) wat slegs instandgehou word uit lippediens aan die Kerkorde. Daar is blykbaar selfs ringe wat slegs vergader om 'n Ringskommissie te kies. Van onderlinge besorgdheid, hulp en meelewing is daar min sprake.

In die lig van die storm wat die kerk en gemeentes tans trotseer, is dit krities belangrik om, in plaas van negatief en afwysend oor die ring te dink (vgl. Strauss 2010:63), dit op 'n kreatiewe wyse volgens die eise van omstandighede te reformeer tot ' $n$ vergadering waar gemeentes weer daadwerklik verantwoordelikheid vir mekaar se totale welsyn aanvaar. Gemeentes het mekaar nodig om te kan bly swem.

\section{GEBORE UIT NOOD}

In die tweede helfte van die sestiende eeu was die bedieningsnood in gereformeerde gemeentes in Nederland akuut (Bouwman 1934:163; vgl. De Jong 1980:223). Predikante wat goedgeskool in die gereformeerde leer was, was skaars (Bouwman 1934:146; Spoelstra 1989:259). Baie gemeentes is bedien deur leraars met gebrekkige teologiese opleiding. Dié toestand van sake was te wyte aan die vervolgings en druk waaronder die gereformeerde kerke in Nederland en Engeland gebuk gegaan het, asook die feit dat baie uit die Rooms-Katolieke en Lutherse kerke gekom het. Dit was dus noodsaaklik dat hierdie bedieningsnood in gemeentes aangespreek word ter wille van die ware kerkwees van gemeentes (Bouwman 1934:124; vgl. Artikel 2 van die Weselse Artikels van 1568 in Biesterveld \& Kuyper 1905:2). Die suiwer bediening van die Woord en sakramente is immers twee kenmerke waaraan die ware kerk uitgeken kan word (Nederlandse Geloofsbelydenis artikel 29).

Reeds sedert die veertiger jare van die sestiende eeu het predikante in Genève en op ander plekke in Switserland vergader "ter bespreking van de $\mathrm{H}$. Schrift, en tot handhaving van de eenheid der leer en het welzijn der kerk" (Bouwman 1934:125). Soortgelyke byeenkomste is ook in Frankryk, Nederland en onder die vlugtelinggemeentes in Engeland gehou ter wille van die goeie orde in die gemeentes en onderlinge lering, vermaning en toesig (Coertzen 1984:9). Op die Konvent van Wesel 1568 word die moontlikheid van iets soos 'n klassis die eerste keer genoem (Biesterveld \& Kuyper 1905:1evv). Tydens die daaropvolgende Sinode van Emden word hieraan formeel gestalte gegee met die reëling in artikel 7: 
Beneven desen Consitorien, sullen oock alle drie ofte ses maenden Classische versamelinghen ghehouden werden van sommighe Kercken die by een gheleghen zijn, nae hare gheleghentheyt ende nootdruft (Biesterveld \& Kuyper 1905:36).

Die gereformeerde gemeentes wat destyds in Duitsland, Oos-Friesland en Engeland verstrooi was, asook alle kerke onder die kruis, moes jaarliks vergader. Enkele reëlings is ook in die volgende artikel getref oor die indeling van die gemeentes in klassisse.

Volgens Bouwman (1934:126ev) was hierdie instelling noodsaaklik vanuit die eenheid van die gemeentes in Christus, omdat die gemeentes mekaar se hulp nodig het vir hulle instandhouding, uitbreiding en die suiwerheid van hulle geloof en lewe, sodat die vryheid van die gemeente gehandhaaf word, as waarborg teen die oorheersing en willekeur van ampsdraers, sodat alles in die gemeente geskied volgens die Woord van God en sodat die orde en tug in die gemeente gehandhaaf word. Die welsyn en opbou van gemeentes was duidelik in die $\mathrm{oog}^{3}$. Juis daarom dat die Sinode van Emden 1571 alle gereformeerde gemeentes in klassisse ingedeel het, ook dié in verstrooiing (Biesterveld \& Kuyper 1905:36ev). Die bedoeling was dat elke gemeente op 'n klassis verteenwoordig sou wees, teenoor sinodes waar slegs verteenwoordigers uit elke klassis teenwoordig was, die sogenaamde trapsgewyse afvaardiging.

Daaropvolgende Sinodes het die frekwensie van vergadering hoër gemaak. Die Nasionale Sinode van Dordrecht 1574 het in artikel 10 bepaal dat dit maandeliks moet gebeur (Biesterveld \& Kuyper 1905:65) en in 1578 in artikel 26 dat die klassikale vergadering elke maand of ses weke moet vergader, of korter of langer, maar sodat daar nie drie maande verbygaan sonder dat 'n vergadering gehou is nie (Biesterveld \& Kuyper 1905:104ev). In sommige gevalle het die klassis elke twee weke vergader. Een vergadering per maand is gewy aan meer administratiewe kerklike sake en die ander vergadering aan 'n gesprek oor leerkwessies. In 'n ander streek het die predikante weekliks of twee-weekliks vergader, ook om leerkwessies te bespreek (Bouwman 1934:141). Om so gereeld moontlik te vergader, was, gegewe die omstandighede destyds, noodsaaklik vir 'n gesonde gemeentelike bediening (vgl. Spoelstra 1989:248). Waarskynlik op die voetspoor van 'n gebruik tydens predikantebyeenkomste in Genève, het die Sinode van Emden 1571 bepaal dat 'n predikant tydens die klassikale vergadering 'n preek moet lewer wat deur die ander afgevaardigdes beoordeel moes word, nie om fout te soek nie, maar "zoo daar iets is te verbeeteren, dan zullen zy te kennen geven" (Biesterveld \& Kuyper 1905:56). Volgens Bouwman (1934:146) was

3 Die kerkorde as uitvloeisel uit 'n dienende kerkreg is daar ter wille van 'n gesonde kerklike lewe (Strauss 2010:4). Die Sinode van Emden 1571 se formele kerkordelike instelling van die klassis is sprekend hiervan. 
die bedoeling van die klassikale prediking nie die stigting van die vergadering nie, maar om die prediking in die gemeentes oor die algemeen ten goede te kom. Dit was dus "opleidingsgeleenthede", gebore uit 'n diepe besorgdheid oor die welsyn van die gemeentes. Bouwman (1934:147) merk op dat die klassikale preek mettertyd verval het soos wat die opleiding van predikante verbeter het.

Onderlinge sorg as funksie van die klassis is in die volgende dekades verbreed en kulmineer in die bepalings wat die Sinode van Dordt in 1618/19 in artikel 41 vir die klassis neerlê (Biesterveld \& Kuyper 1905:236). Klassikale vergaderings bestaan uit naburige gemeentes wat minstens elke drie maande vergader deur middel van 'n predikant en ouderling as afgevaardigdes. Tydens elke vergadering moes die voorsitter aan elke gemeente vra of hulle kerkraadsvergaderings hou, of die kerklike dissipline uitgeoefen word, of die armes en skole versorg word en of hulle die hulp van die klassis benodig vir hulle gemeentelike inrigting. Tydens elke klassis moes 'n predikant wat tydens die vorige vergadering aangewys is, 'n preek lewer met die oog op verbetering van die prediking.

Die reëling dat die klassis betrokke is by die toelating van predikante tot die amp en die beroeping van die predikante deur gemeentes, was ook ' $n$ wyse waarop die klassis toesig gehou het oor die leer (Bouwman 1934:148). Geskikte en goed toegeruste mense was nodig vir die gesonde bediening van die gemeentes. Ook op hierdie manier het die klassis verantwoordelikheid vir die welsyn van gemeentes aanvaar.

\section{KERKVISITASIE AS VERSORGING}

$\mathrm{Na}$ enkele geluide daaroor op voorafgaande provinsiale sinodes, stel die Nasionale Sinode van Den Haag in 1586 kerkvisitasie as funksie van die ring $\mathrm{in}^{4}$, as uitdrukking van die verantwoordelikheid wat naburige gemeentes vir mekaar neem (Biesterveld \& Kuyper 1905:202, 220; Bouwman 1934:164). Volgens Nauta (1971:200) is kerkvisitasie ingestel omdat daar besef is dat dit wat tydens klassikale vergaderings gebeur nie genoegsaam is vir die klassis

$4 \quad$ Spoelstra (1989:258) is van mening dat kerkvisitasie nie 'n funksie van die klassis is nie. Visitatore word volgens hom wel deur die klassis aangewys, maar tree nie namens die klassis op nie en doen ook nie aan die klassis verslag nie. Uit artikel 44 van die Kerkorde van die Sinode van Dordt 1618/19 blyk egter 'n nou band tussen kerkvisitasie en dit wat die klassis se funksie is (Biesterveld \& Kuyper 1905:237). Die visitatore is kennelik 'n kommissie van die klassis in diens van die opsigtaak van die klassis en moet daarom verslag doen (Nauta 1971:199, 206). Strauss (2010:54) stel dit selfs sterker deur te sê dat kerkvisitasie die primêre werkswyse van die ring is. 
om sy doel te bereik nie. Die beter onderlinge sorg wat dit meegebring het, het gesorg dat kerkvisitasie 'n funksie van die klassis geword het. Opsig oor die leer en lewe van predikante en die toestand van die gemeentes was immers in die oog.

Hierdie was nie 'n vreemde gebruik in die geskiedenis van die kerk nie. Bouwman (1934:157ev) brei breedvoerig hierop uit. In die vierde eeu na Christus was dit reeds die gewoonte dat biskoppe of hulle afgevaardigdes hulle diosese jaarliks besoek om die woord en sakramente te bedien en ondersoek in te stel na verskeie aspekte van die gemeentelike lewe en die ampswerk. Mettertyd het dit egter ontaard in kerklike howe met allerlei wanpraktyke in swang. Tydens die reformasie het gesonde kerkvisitasie onder die Lutherane, die kerk 'n groot diens bewys. Die doel was om te sorg dat God op die regte manier vereer word, kerklike sake te orden en die gemeentelike lewe op te bou. Onderrig aan visitatore is noodsaaklik geag om, teenoor die wanpraktyke van die Rooms Katolieke, visitasie weer op die regte spoor te bring. Calvyn het in 1546 visitasie in Genève ingebring met die oog op die ampswerk en suiwer leer en lewenswandel van predikante en die erediensbywoning deur lidmate. In Skotland het John Knox visitasie in 1561 ingevoer om nuwe gemeentes te organiseer en toesig te hou oor die ampswerk van predikante.

Visitasie was aanvanklik met gemengde gevoelens in die Nederlandse kerk ontvang vanweë negatiewe gevoelens oor kerklike inspeksie en heerskappy (Bouwman 1934:164ev). Die Nasionale Sinode van Dordt 1618/19 het in artikel 44 van sy Kerkorde kerkvisitasie egter verpligtend gemaak met die doel om oor die suiwerheid van die leer te waak, om toe te sien dat daar volgens die kerklike orde geleef word en om gemeentes met goeie raad te bedien (Bouwman 1934:166). Dit staan dus in diens van die besorgdheid van gemeentes oor mekaar se welsyn. Hierdie onderlinge verantwoordelikheid het swaarder geweeg as die moontlike misbruik wat hiermee gepaard kon gaan (vgl. Coertzen 1984:36).

\section{4. 'N BEHOEFTE AAN 'N MEERDERE VERGADERING AAN DIE KAAP}

Die eerste Kaapse gemeentes het as buitelandse gemeentes volgens ' $n$ besluit van die Sinode van Noord-Holland in 1642, onder die Klassis van Amsterdam gesorteer (Kleynhans 1973:281). Uiteraard het afstand die kwessie van naburigheid in gedrang gebring (vgl. Coertzen 1984:22). Geen Kaapse gemeente het ooit verteenwoordiging in die Klassis of die Sinode van Noord-Holland gehad nie. Die verhouding met die meerdere vergaderings in Nederland is wel gehandhaaf deur middel van wedersydse korrespondensie. Die Klassis van Amsterdam het gereelde verslag oor die stand van die 
gemeentes verwag en is ook deur die Kaapse gemeentes geraadpleeg. Kleynhans (1973:283) merk dan ook op dat hoewel daar geen formele plaaslike verband tussen die Kaapse gemeentes bestaan het nie, hulle tog in hulle gesamentlike verbondenheid aan die Klassis van Amsterdam aan mekaar gebonde gevoel het. Die plaaslike owerheid het ook as skakel tussen die gemeentes gedien.

Hierdie toedrag van sake is mettertyd as 'n leemte beleef. In 1707 is twee kerkrade met toestemming van die owerheid die eerste keer gekombineer om ' $n$ klagte teen ' $n$ lidmaat te hanteer, maar dit was onbevredigend volgens korrespondensie wat daaroor aan die Klassis van Amsterdam gerig is (Kleynhans 1973:284). In die volgende dekades was daar meermale versugtinge uitgespreek en voorstelle gemaak vir'n meerdere vergadering aan die Kaap. In die hart hiervan was die behoefte tussen die Kaapse gemeentes om mekaar onderling by te staan deur middel van ' $n$ amptelike meerdere vergadering en die oortuiging dat dit plaaslik beter gedoen kan word as deur die verre Klassis van Amsterdam.

\subsection{Die Gekombineerde Kerkvergadering}

In Julie 1745 gelas die Politieke Raad aan die Kaap die kerkrade van die verskillende gemeentes om 'n gekombineerde kerkvergadering saam te roep om die verdeling en grense vir twee nuwe gemeentes te bespreek (Kleynhans 1973:287). Dié byeenkoms is op 30 Augustus 1745 in Kaapstad gehou. Benewens die reëling van die grense van die vyf gemeentes, het hierdie vergadering ook die noodsaaklikheid van 'n jaarlikse klassikale vergadering beklemtoon sodat alle plaaslike kerklike sake behoorlik hanteer kan word (Handelinge Gekombineerde Kerkvergadering 1745-59:6). Dit is as 'n versoek aan die plaaslike owerheid gerig, wat dit dan ook goedkeur het (Kleynhans 1973:287). Die Klassis van Amsterdam wou egter nie toestemming gee dat dit as 'n klassis beskou word nie. Daarom is besluit om te volstaan met die term Gekombineerde Kerkvergadering (Handelinge Gekombineerde Kerkvergadering 1745-59:15).

Alhoewel nie formeel en amptelik nie, was hierdie vergadering vir alle praktiese doeleindes 'n klassis vir die gemeentes aan die Kaap (Vorster 1981:114ev). Dit het alles gedoen wat die Dordtse Kerkorde vir die klassis bepaal, behalwe dat die Gekombineerde Kerkvergadering nie voornemende predikante tot die bediening toegelaat het nie. Dat 'n duidelike onderlinge besorgdheid oor mekaar se welsyn grondliggend aan die behoefte tot 'n meerdere vergadering was, blyk duidelik uit die verklaring tydens die vergadering van 1748 dat die byeenkoms sal strek "tot welzijn van Gods Kerck in't algemeen, en in't bijzonder van de Gemeentes in Africa" (Handelinge 
Gekombineerde Kerkvergadering 1745-59:13) en die instelling van kerkvisitasie deur die vergadering van 1752: “... om een jaarlijksche kerken-visitasie te doen tot onderlingen liefde en vrede" (Handelinge Gekombineerde Kerkvergadering 1745-59:30). 'n Visitasiereglement word tydens die vergadering van 1754 goedgekeur (Handelinge Gekombineerde Kerkvergadering 1745-59:37). Volgens die Reglement moes navraag gedoen word na onder andere die gereelde hou van eredienste op Sondae, die suiwer bediening van die sakramente, of die doopformulier onveranderd gelees word, of die ouderlinge saam met die leraar verantwoordelikheid neem dat lidmate hulle in leer en lewe reg gedra en hulle beywer om alle ergernisse uit die weg te ruim, of die diakens verantwoordelikheid neem vir die armsorg en of die finansies reg bestuur word. Die welsyn van gemeentes was duidelik in die oog.

Dit word dan ook allerweë betreur dat die Kaapse owerheid in 1759 'n einde gemaak het aan die Gekombineerde Vergadering. Dit was teen die wense van die Klassis van Amsterdam en van die Kaapse gemeentes, wat hierdie amptelike organisering van hulle onderlinge sorg vir mekaar, terdeë sou mis (Kleynhans 1973:290evv; Vorster 1981:119evv).

\section{DIE KLASSIS VERVAL TOT 'N ADMINISTRATIEWE LIGGAAM}

In die Algemene Reglement van die Nederlandse Gereformeerde Kerk van 1816 word die klassikale vergadering, tipies kollegialisties 'n blote bestuursvergadering wat as skakel optree tussen gemeentes en die sinodes. Enkele administratiewe sake moes op die jaarlikse vergadering gereël word (vgl. Algemene Reglement 1816 artikels 49-67 in Pont 1991:36evv). Interessant genoeg maak die Reglement egter ook voorsiening dat klassisse in ringe ingedeel word. In artikel 80 word duidelik gesê dat ringe nie 'n bestuursfunksie het nie, maar dien tot "onderlinge opscherping en versterking van den band der broederlijke liefde" (Pont 1991:40; vgl. Coertzen 1984:11). Ringe, wat in wese predikantebyeenkomste was, moes sorg vir vakante gemeentes, godsdienstige onderwerpe behandel wat die opbloei van die Christendom, die bevordering van Bybelkennis en die waarneem van hulle bediening, insluit. Waar die klassis 'n bestuursfunksie gekry het, is die onderlinge sorg vir gemeente weliswaar nie nagelaat nie, maar oorgelaat aan hierdie predikantebyeenkomste. Hiermee is weggedoen met die gereformeerde beginsel dat meerdere vergaderings, vergaderings van gemeentes is wat onderlinge sorg vir mekaar aanvaar (vgl. Coertzen 1984:11). Die ring was egter wel 'n byeenkoms ter wille van die welsyn van gemeentes. 


\section{DIE RING EN ONDERLINGE SORG SEDERT 1824}

\subsection{Die Ordonnansie van De Mist 1804}

Engeland het in 1795 die bewind aan die Kaap oorgeneem. Hiermee is formele betrekking tussen die Kaapse gemeentes en die klassis van Amsterdam vir 'n kort wyle feitlik onmoontlik gemaak (Kleynhans 1973:294). Nog voor die heroorname deur die Bataafse bewind in 1803, is korrespondensie met Klassis van Amsterdam hervat (Kleynhans 1973:294ev). In 1804 skryf die Kerkraad van Kaapstad aan die kommissaris-generaal de Mist oor die vrye verkiesing van kerkraadslede en die noodsaaklikheid van 'n Gekombineerde Kerkvergadering vir die gemeentes aan die Kaap (Kleynhans 1973:295ev). As redes word aangevoer dat elke gemeente in werklikheid op sy eie staan, dat dit sal bydrae tot die goeie orde en eensgesindheid in gemeentes en om onderhorigheid aan die bestaande Kerkorde te bevorder. Dit gaan dus om 'n meer formele band tussen die gemeentes ter wille van hulle welsyn en die welsyn van die kerk in die algemeen. Dit is duidelik in die skrywe gestel dat die verlangde Gekombineerde Kerkvergadering nie bedoel is om ' $n$ klassis te wees of die bande met die Klassis van Amsterdam te verbreek nie. In dieselfde jaar stel De Mist 'n kerkorde op waarin voorsiening gemaak word vir slegs 'n Algemene Kerkvergadering (Kerkordonnansie 1804 artikel 46 in Pont 1991:188). Die inisiatief om dit te reël word aan die Kerkraad van Kaapstad oorgelaat. Die funksie van hierdie vergadering word baie vaag omskryf as om aan die owerheid die sekerheid te gee dat aan die bepalings van die Kerkordonnansie nagekom word (vgl. Kleynhans 1973:226ev). In artikel 48 word bepaal dat nadere besonderhede oor die inhoud van die Algemene Kerkvergadering wat minstens elke twee jaar moes vergader, in 1805 gereël sal word.

\subsection{Die Sinode van 1824}

Die eerste Algemene Kerkvergadering of Sinode het egter eers in 1824 plaasgevind, en het hoofsaaklik aan 'n kerkorde aandag gegee. In hierdie Kerkorde word, benewens die kerkraad, ook in artikel 1 voorsiening gemaak vir twee meerdere vergaderings: die sinode en die ring (Pont 1991:216). Vir die eerste keer word 'n meerdere vergadering 'n ring genoem. Op voetspoor van die kollegialistiese Algemene Reglement van 1816 het dit egter grootliks 'n bestuursfunksie gehad en was dit gesien as tweede in die hiërargie van kerkraad, ring en sinode, met laasgenoemde as die hoogste gesag (Algemene Reglement 1824 artikel 9 in Pont 1991:217). Die Sinode het die gemeentes in drie ringe verdeel, en uit die indeling is dit duidelik dat hulle uitvoering gegee 
het aan die beginsel dat die ring saamgestel word uit naburige gemeentes (Kleynhans 1973:209).

Daar word feitlik niks in die Algemene Reglement van 1824 gesê oor die funksie en werksaamhede van die ring nie. Weliswaar word in artikel 15 besluit dat die Algemene Kerkvergadering of die Ringsbestuur (Ringskommissie-AC) met approbasie deur die Algemene Kerkvergadering 'n kerkvisitasiereglement moet opstel. Dié is na inagneming van voorstelle uit die ringe in 1826 tydens die volgende Algemene Kerkvergadering goedgekeur. Hiervolgens moet elke gemeente se afgevaardigdes antwoord op 'n reeks van drie-en-twintig vrae wat deur die voorsitter gestel word. Dit het 'n wye spektrum van die geestelike, administratiewe en materiële aspekte van gemeentewees aan die orde gestel. Die totale welsyn van elke gemeente was hierdeur onder oë geneem.

\subsection{Die Wette en Bepalinge van 1842}

Die Sinode van 1842 het die bestaande Algemene Reglement en Kerkorde van de Mist vervang met "Wetten en Bepaling voor het Bestuur der Nederduitsche Gereformeerde Kerk in Zuid-Afrika" (Kleynhans 1973:131). Hierin word die Ring onder andere belas met die sorg vir die belange van die godsdiens, die bewaring van die goeie orde en die handhawing van die kerklike wette in hulle resort, die eksaminering van kerklike onderwysers, die bevordering van godsdienstige onderwys, die sorg vir die vermeerdering van gemeentes, die aanwys van konsulente vir vakante gemeentes en die doen van kerkvisitasie (Kleynhans 1973:214). 'n Interessante besluit van die 1842 Sinode oor die werksaamhede van die ring is die bepaling dat met sinodes wat elke vyf jaar moes vergader, ringe volmag gekry het om spoedeisende sake wat op hulle agenda kom en wat eintlik by die Sinode hoort, af te handel op voorwaarde dat dit binne die ruimte van die kerklike bepalings moes geskied (Kleynhans 1973:214). Hiermee wou die Sinode voorkom dat gemeentelike belange skade ly vanweë belangrike sake wat nie dadelik hanteer kan word nie. Die welsyn van gemeentes was belangrik.

\subsection{Kerkvisitasie}

Die Sinode van 1842 het in artikel 34 bepaal dat kerkvisitasie, op voetspoor van die Reglement van 1826 , by wyse van 'n aantal vrae wat tydens die ringsvergadering skriftelike beantwoord moes word, moes geskied (Kleynhans 1973:216). Alhoewel die Dordtse Kerkorde van 1618/19 en die Visitasiereglement van die Gekombineerde Kerkvergadering 1752 voorsiening gemaak het vir persoonlike kerkvisitasie, was skriftelike kerkvisitasie ongelukkig vir baie lank aan die orde, nie net binne die Nederduitse Gereformeerde Kerk 
in Suid-Afrika nie, maar ook in ander sinodale gebiede. Hierdie meer saaklike manier waarop die situasie van gemeentes aan die orde gekom het, het afbreuk gedoen aan die onderlinge besorgdheid tussen gemeentes wat so kenmerkend was van die tyd in die geskiedenis toe die klassis (of ring) sy verskyning in kerklike regering gemaak het (Coertzen 1984:36; vgl. Bouwman 1934:174; Flemming 1961:447ev; Du Toit 1991:136). Die Algemene Sinode van die Nederduitse Gereformeerde Kerk het in sy kerkorde kerkvisitasie deel gemaak van die opdragte aan die ring (Kleynhans 1985:53). Ten spyte van versoeke om persoonlike kerkvisitasie as 'n kerkordelike vereiste in te stel, is die status quo ongelukkig tot op hede gehandhaaf (Ned Geref Kerk 1966:563; Ned Geref Kerk 1970:700, 840). Sommige sinodes het wel die lofwaardige besluit geneem dat kerkvisitasie persoonlik deur 'n kommissie gedoen moet of kan word (Coertzen 1984:36). Die Sinode van Noord-Kaapland het byvoorbeeld op persoonlike kerkvisitasie (of gemeentebesoek, soos hulle

dit later genoem het) besluit omdat dit die beste manier is waarop ' $n$ ring eerstehands kennis kan neem van die situasie in 'n gemeente en so mekaar se laste te kan help dra (Ned Geref Kerk Noord-Kaapland 1983:565).

\subsection{Die Ring sedert 1962}

Die Algemene Sinode van 1962 het benewens die bepaling oor kerkvisitasie, onder ander ook in artikel 31 van die Kerkorde bepaal dat tot die werksaamhede van die ring behoort: die opsig oor die gemeentes, om toe te sien dat kerkrade en gemeentes hulle roeping nakom, advies en hulp aan kerkrade en die aanwys van konsulente vir vakante gemeentes (Kleynhans 1985:53). Met hierdie artikels is die welsyn van elke gemeente op die agenda van die ring. Opsig staan in hierdie verband in die teken van sorgdra, bekommerd wees oor en gemoeid wees met (Coertzen 1984:33ev). Die kernvraag wat naburige gemeentes tydens vergaderings van die ring vir mekaar behoort te vra, is: "Hoe gaan dit in die gemeentes?". Hiermee word Paulus se opmerking aan Barnabas in die eerste eeu na Christus, twee millennia later steeds in die kerk van Jesus Christus geëggo:

Kom ons gaan kyk hoe gaan dit met die gelowiges in al die stede waar ons die woord van die Here verkondig het (Handelinge 15:36, NAV).

\section{DIE RING SE AGENDA GEWORTEL IN DIE NUWE TESTAMENT}

Die onderlinge besorgdheid oor die welsyn van die gemeentes en die saamvergader om mekaar daarmee te help, het sy wortels in die kerk van die Nuwe Testament. 


\subsection{Die sogenaamde Apostelkonvent}

Die Nuwe Testament ken nie enige formele struktuur of organisasie waardeur gemeentes aan mekaar verbind is nie (Celliers 2003:315). Die sogenaamde Apostelkonvent (Handelinge 15) word wel deur sommige gereformeerdes beskou as "een soort synode" (Bouwman 1934:190), maar dit is uit beide sy samestelling en werkswyse duidelik dat dit nie as 'n meerdere vergadering in gereformeerde sin beskou kan word nie ${ }^{5}$. Tog is die vergadering in Jerusalem 'n duidelike uitdrukking van die eenheidbewussyn en onderlinge besorgdheid wat destyds tussen Christene en gemeentes bestaan het. Die rede vir die vergadering was uitsluitsel oor die waarheid van die evangelie ter wille van die eenheid van die kerk (Dunn 1996:195evv; Van Zyl 1989:59ev). Daarvoor is Paulus en etlike ander deur die gemeente in Antiogië na Jerusalem gestuur omdat die apostels daar was. Die besluit wat geneem is, is per brief en afvaardiging na al die gemeentes gestuur. Almal moes kennis neem en hieraan gehoor gee. Die saak het die evangelie en die ware kerkwees van gemeentes geraak.

\subsection{Jesus se gebed om eenheid}

Hierdie eenheidsbewussyn en onderlinge besorgdheid tussen Christene en gemeentes kom op verskeie ander maniere en Skrifgedeeltes in die Nuwe Testament na vore. In Jesus se gebed in Johannes 17 bid Hy nie net vir die eenheid tussen die dissipels self nie, maar ook vir die eenheid tussen die wat tot geloof sal kom deur die getuienis van die dissipels. Wanneer byvoorbeeld Johannes 10:16 met sy klem op een herder en een kudde, hiermee saamgelees word, versterk dit die gedagte dat hierdie eenheid betrekking het op die totale gemeenskap van gelowiges, en dat dit om meer gaan as bloot 'n geestelike eenheid (Dunn 1977:118; Brown 1966:evv). Dit is uit hierdie gedeelte duidelik dat die konkrete eenheid van die totale gemeenskap van gelowiges 'n gawe en 'n gegewe uit die hand van God is.

\subsection{Ekklesia as uitdrukking van eenheid}

Die eenheidsbewussyn wat in die vroeë kerk bestaan het, word verder duidelik uit die wyse waarop die woord ekklesia gebruik word. In Matteus

5 ' $n$ Meerdere vergadering is ' $n$ vergadering van gemeentes deur middel van hulle afgevaardigdes (Kleynhans 1985:142). Die Apostelkonvent was'n vergadering waar afgevaardigdes uit Antiogië 'n dringende saak met die apostels as gesaghebbende ooggetuies van Jesus se lewe en opstanding en die ouderlinge in Jerusalem kom bespreek het. Diegene wat aangedring het op die besnydenis was ook uit Judea afkomstig (Handelinge 15). 
16:18 verwys dit in die enkelvoud na die algemene kerk en in Matteus 18:17 na 'n spesifieke gemeenskap van gelowiges. Jeremias (1971:168) maak 'n argument daarvoor uit dat in die lig van die beelde wat Jesus vir die nuwe volk van God gebruik, die woord ekklesia in Matteus eerder vertaal behoort word met "volk van God", as met kerk. In Handelinge word die enkelvoud gebruik vir beide 'n gemeente (Handelinge 5:11) en vir die algemene kerk (Handelinge 9:31). Die meervoud word ook gebruik vir meer as een gemeente. Ook Paulus gebruik die enkelvoud enersyds vir 'n bepaalde gemeente (1 Korintiërs 1:2) en andersyds vir die algemene kerk (Efesiërs 1:22 en Kolossense 1:18).

\subsection{Eenheid as onderlinge opdrag}

Die Nuwe Testamentiese kerk het egter nie net hulle onderlinge eenheid gesien as 'n gegewe nie. Hulle het dit ook as 'n opdrag van die Here aan sy kerk aanvaar. Roberts (1983:107ev) merk oor Efesiërs 4:1-6 op:

Op ' $n$ baie besondere wyse stel hierdie perikoop die punt dat die eenheid van die kerk ' $n$ integrerende deel is van sy belydenis, van die leer van die kerk dus. Verder maak dit ook duidelik dat met die eenheid waaroor dit hier gaan, as eenheid in Christus, nie 'n vae, onwerklike, 'geestelike' eenheid bedoel word nie. Inteendeel, die wesenlike eenheid wat in die heilswerk van Christus gegee is, is 'n praktiese, sigbare eenheid. Christene moet so optree dat hulle dit met mekaar uithou en nie van mekaar weggedryf word nie. Gebeur laasgenoemde, word die eenheid verbreek en is die Christene ongehoorsaam en hulle lewenswandel nie in ooreenstemming met die evangelie wat hulle aanvaar het nie.

Floor (1995:141) wys daarop dat die brief aan die gemeente in Efese beide die universele kerk en die gemeente as plaaslike uitdrukking van die universele kerk in die oog het. Die vermaning om die Geesgesmede eenheid te handhaaf, het nie net betrekking op die gemeente in Efese nie, maar geld ook vir die universele kerk ${ }^{6}$. Elke gemeente was 'n mikrokosmos van die hele kerk.

$6 \quad$ Floor (1995:141) wys die standpunt af dat die brief aan die Efesiërs slegs die algemene kerk in die oog het. Dit gaan tereg volgens hom in hierdie brief veral oor die universele kerk, maar hy beklemtoon dat Efesiërs 4 ook die praktiese gemeentelike lewe van die Christene in Efese in die oog het en skryf daarop: "Zoals de algemene kerk het lichaam van Christus is, zo is de plaatselijke kerk dat eveneens. ... de universele kerk komt in de plaatselijke kerk tot openbaring". 
Each group of believers was united in Christ and found a strong affinity with other groups who were similarly united, for all were under the authority of the same Lord (Guthrie 1981:741).

\subsection{Onderlinge besorgdheid}

Die eenheidsbewussyn tussen die eerste Christene, word ook duidelik uit die onderlinge besorgdheid tussen hulle. Uit Paulus se briewe is dit duidelik dat hy hom voortdurend bekommer het oor die geestelike toestand van die gemeentes wat deur hom gestig is (De Villiers 1983:34). Sy uitnodiging aan Barnabas in Handelinge 15:36 (NAV) druk iets hiervan uit: "Kom ons gaan kyk hoe gaan dit met die gelowiges..." . Du Toit (1984:2) stel dat dit hierdie "besorgdheid oor al die gemeentes" is, wat die skrywers van die Nuwe Testamentiese Briewe na die pen laat gryp het. 'n Geheeloorsig oor die Nuwe Testament bring na vore dat dié besorgdheid oor Christene en gemeentes se verhouding met die Here, 'n gehoorsame lewenswyse en 'n suiwer belydenis, gegaan het. Verskille oor enige van hierdie sake kan die eenheid van die kerk in gedrang bring. Die eenheid is immers 'n geloofseenheid, soos dit uitgedruk word in die feit van geloof, wat geglo word en hoe geloof uitgeleef word (Celliers 2003:222).

\subsection{Materiële sorg}

Die eenheidsbewussyn en onderlinge besorgdheid tussen die eerste gemeentes, blyk ook uit die kollekte wat vir Jerusalem ingesamel is (byvoorbeeld 2 Korintiërs 8:1-15 en 9:1-15; Pop 1980:239ev). As gevolg van verskeie redes het dit op 'n stadium materieel baie swaar met die Christene in Jerusalem gegaan. Paulus skryf op meer as een plek oor die vrygewigheid waarmee Christene op ander plekke geld ingesamel het vir hulle geloofsgenote. Baie van hulle was self arm. Hierdie onderlinge meelewing onderstreep ook die eenheidsbewussyn waarop reeds gewys is. Daar was eenvoudig die besef dat al die gemeentes aan mekaar verbonde is, en mekaar nodig het om werklik kerk te wees in die wêreld (vgl. Guthrie 1981:741).

7 Handelinge 15:36 word as "de nervus visitationus ecclesiasticae" beskou (Bouwman 1934:173). Die aanvanklike motief van Paulus se tweede sendingreis was nie die planting van nuwe gemeentes nie, maar 'n besorgdheid oor die bestaande gemeentes. Dunn (1996:210) maak dan oor hierdie vers gewag van Paulus se "pastoral concern", wat ook op ander plekke in die Nuwe Testament duidelik deurslaan. 


\subsection{Eenheid as getuienis}

Daar was egter ook die besef dat die eenheid tussen hulle deel is van hulle roeping as kerk van Jesus Christus. In sy hoëpriesterlike gebed waar Jesus om die eenheid van sy dissipels en diegene wat deur hulle getuienis tot geloof sal kom, bid, bid Hy ook dat hierdie eenheid sigbaar sal wees, "sodat die wêreld kan glo dat U my gestuur het" (Johannes 17:21, NAV). Die eenheid onder gelowiges het duidelike implikasies vir die roeping van die kerk van Jesus en dus van elke gemeente ${ }^{8}$.

Vir gereformeerdes is kerkverband 'n uitdrukking van die eenheid van die kerk (Spoelstra 1989:248). Wanneer gemeentes in kerkverband met mekaar tree, en as 'n eerste uitdrukking hiervan in ringsverband vergader (in hulle eie omgewing), is dit in gehoorsaamheid aan hulle God se opdrag. Die ring het dus opsig self reeds 'n getuienisfunksie en mag daarom nie opsioneel raak nie.

\section{DIE WEG VORENTOE}

\section{1 'n Reformasie in denke}

Indien Pienaar (2010:8) reg is wanneer hy skryf:

So sterk het sommige individuele gemeenteteologieë en -begrotings geword, dat die skeptiese en apatiese afstand met die res van die kerk opvallend is. 'Eintlik het ons julle nie nodig nie. Julle behoort dit in ons lyftaal te lees. Ons het alles en kan alles doen wat nodig is',

is die huidige kerklike situasie binne die Ned Geref Kerk en haar familie ver verwyder van dit wat tussen die eerste gemeentes en Christene geleef het $^{9}$. Dit plaas geweldige druk op die verhouding tussen gemeentes, of te wel kerkverband soos gereformeerde Christene die Skrif daaroor verstaan. Kerkverband is immers niks anders nie as gemeentes wat konkreet gestalte daaraan gee dat hulle in 'n noue verhouding met mekaar saamleef omdat

8 "Unity is impressed on the Church as an essential characteristic, for Christ draws the Church into the existing indissoluble communion between Father and Son; consequently unity must also take effect perfectly and distinguish the Church, so that the world may believe in the divine mission of Christ" (Schnackenburg 1974:111).

9 "Dit is onverstaanbaar dat ons soms dink dat ons die insig en hulp van die kerkverband nie nodig het nie" (Strauss 2010:65). 
hulle dieselfde glo en dinge ( $m i n$ of meer) op dieselfde manier doen en wat dit dus wenslik maak om sekere dinge saam te doen ${ }^{10}$ (Strauss 2010:53, 64).

Die titel van hierdie artikel is tekenend van die gereformeerde kerkregtelike denkwyse oor die ring as 'n meerdere vergadering. Kerkreg is 'n dienende reg (Strauss 2010:1). Wanneer die Kerkorde van die Ned Geref Kerk in artikels 18 en 29 voorsiening maak vir die ring, staan dit onder die teken van diens. Gemeentes kom bymekaar om mekaar te versorg op geestelike, materiële en administratiewe terrein. Dit sal tans waarskynlik 'n reformasie van denke en gesindheid kos vir gemeentes om weer werklike erns te maak met die gegewe dat hulle, as volledige kerke, mekaar in werklikheid nodig het om hulle Godgegewe roeping na binne en na buite gehoorsaam uit te leef ${ }^{11}$.

\subsection{Enkele wegwysers}

- Die ring se optrede in vergaderings en wat daaruit voortvloei mag nie gekenmerk word deur 'n saaklike en juridiese karakter nie, maar moet pastoraal van aard wees. "Opsig oor die gemeentes, om toe te sien dat kerkrade en gemeentes hulle roeping nakom; hulp en advies aan kerkrade" (Die Kerkorde 2007:16) moet immers pastoraal benader word en nie as inspeksies gesien word nie.

- Wanneer die Kerkorde van die Ned Geref Kerk se uiteensetting van die werksaamhede van die ring in artikel 31 (Die Kerkorde 2007:16ev) vergelyk word met byvoorbeeld dié in artikels 41-44 van die Dordtse Kerkorde van 1618/19 (Biesterveld \& Kuyper 1905:236evv), is dit opvallend dat eersgenoemde baie minder detail bevat in sy uiteensetting van die taak van die ring ${ }^{12}$. Dit skep baie ruimte vir 'n kreatiewe inkleding van die werksaamhede van die ring na die eise van eie omstandighede. Ringe hoef nie bang te wees om binne hierdie ruimte hulle werkswyse drasties aan te pas sou die nood of behoeftes van ringsgemeentes dit vereis nie.

10 "Meerdere vergaderings is ' $n$ gereformeerde noodsaaklikheid omdat gemeentes van dieselfde belydenis en stelsel van kerkregering mekaar natuurlikerwys opsoek in die eenheid van kerkverband. Hierdie 'natuurlikerwys' is gesetel in die aard van kerkwees en daarom die 'natuurlike' struktuur van die kerk' (Strauss 2010:53).

11 "Daar mag vrae oor die funksionering van moderne ringe of klassisse wees, maar die funksie van onderlinge versorging en ondersteuning van mekaar deur die gemeentes van die omgewing bly noodsaaklik" (Strauss 2010:66).

12 Gereformeerdes het oor die algemeen nog altyd daarop aangedring "dat 'n kerkorde nie te veel praktiese detail moet bevat en daarmee die deurwerking van die Skrif en belydenis moet verhinder of verduister nie... 'n Reglementering lei tot kerklike deformasie en strem die hervormingskrag wat daar in die Woord en sy kernwaarhede lê" (Strauss 2010:16). 
- Die groter prentjie, naamlik dié van die gemeente as plaaslike uitdrukking van die algemene kerk, moet die hoek wees waaruit gemeentes in ringsverband na mekaar kyk as teenvoeter vir die ekstreme individualisme en verbruikerskultuur van ons tyd. $\mathrm{Na}$ aanleiding van Efesiërs 4:4-6 kan dit platweg gesê word dat ringsgemeentes moet raaksien dat hulle almal dieselfde Baas het, vir wie hulle in dieselfde omgewing dieselfde werk doen ${ }^{13}$. Van kompetisie van enige soort kan daar mos nie sprake wees nie.

- In die nadenke oor ontluikende kerke ${ }^{14}$ as 'n hedendaagse gestalte van die kerk waarin die sogenaamde postmoderne Christen homself tuis sal voel, word gewys op die feit dat hulle 'n wars het aan enige vorm van hiërargie of dwang van bo (Niemandt 2008:140, 160). Verhoudings, netwerke en plat strukture is binne hierdie kerkbegrip die aangewese weg. In gereformeerde denke ís die ring niks anders nie as 'n plat struktuur waar gemeentes in 'n gelykwaardige verhouding met mekaar saamleef in dieselfde omgewing. Die ringsgemeentes vorm 'n span wat saam kan soek na die wesenlike bestaanswyse vir die kerk in hulle omgewing, 'n moontlike nuwe kultuuromgewing inbegrepe.

- Die ring kan ook verstaan word as 'n netwerk van naburige gemeentes wat uiters geskik is om mekaar met die spreekwoordelike (en letterlike) druk van 'n knoppie te help aan inligting, raad en ondersteuning. Moderne kommunikasietegnologie kan gemeentes in sulke netwerke met mekaar koppel. Besluite en aksies van die ring kan tot in die huis van feitlik elke lidmaat gekommunikeer word. Kennis en deursigtigheid kan die waardering vir die ring se rol in die gemeentes groter maak, misverstande en onnodige kritiek uitskakel (Strauss 2010:66), en so die noodsaaklike reformasie van die ring bevorder.

- Daar kan baie meer van persoonlike kerkvisitasie as die primêre werkswyse van die ring gemaak word (vgl. Strauss 2010:54). 'n Egte belangstelling gebore uit' $n$ werklike besorgdheid oor die totale welsyn van die gemeente, is hier die wagwoord, asook om te luister en te verstaan met die oog om van hulp te wees.

13 "Daar is net één liggaam en net één Gees, soos daar net één hoop is waartoe God julle geroep het. Daar is net één Here, één geloof, één doop, één God en Vader van almal: Hy wat oor almal is, deur almal werk en in almal woon" (Efesiërs 4:4-6 NAV).

14 Volgens Niemandt (2008:139) is ontluikende kerke 'n kerklike of missionêre beweging wat oor denominasionele grense strek; 'n geloofsgemeenskap wat Jesus in 'n postmoderne kultuur volg. Dit kan beskou word as 'n prototipe of eksperimentele kerk wat na die kernwaarhede en wesenlike van die heel vroeë gemeentes soek. 
- Gemeentes sal steeds in formele ringsvergadering byeen moet kom ter wille van goeie besluite oor gesamentlike werksaamhede, kerkregtelike noodsaaklikhede en persoonlike kontak en verhoudings. Dit hoef nie net een keer per jaar te gebeur nie, maar soveel keer as wat nodig is vir optimale hulp aan gemeentes. Uiteraard kan dit van ring tot ring verskil.

- Vergaderings of byeenkomste van die ring behoort so ingerig te word dat daar genoeg ruimte is om saam te besin oor en oplossings te soek vir die vraagstukke, uitdagings en struikelblokke wat in elke gemeente leef (vgl. Strauss 2010:65). Raad en advies hoef nie voorskriftelik te wees nie. Respek vir die geestelike volwassenheid van kerkrade en die volledige kerkwees van gemeentes is die wagwoord ${ }^{15}$. Waar bindende besluite geneem word sal konsensus binne die vergadering, en in die geval van meer kontensieuse sake ook dialoog met die onderskeie kerkrade en/of gemeentes die uitnemende weg wees. Ruim tyd moet afgestaan word om vir elke gemeente te bid. Ter wille van voldoende tyd om aandag aan wesenlike sake te kan gee, hoef net verslae van kommissies met pertinente opdragte en aanbevelings behandel te word. Ander verslae kan op ander maniere vir kennisname onder die aandag van kerkrade gebring word.

- Die feit dat die ring besluite kan neem wat bindend op die gemeentes is, kan binne die denkraamwerk van die ontluikende kerke die indruk skep dat dit vergaderings is wat van bo regeer. Die ring se gesag is egter Woordgesag ${ }^{16}$ (vgl. Coertzen 1984:20). Gemeentes soek saam in die Skrif na die waarheid. Hierdie waarheid mag egter nooit onder druk van die postmoderne tydsgees so relatief word, dat elkeen maar kan glo en doen soos hy wil nie. Die voorbeeld van die Apostelkonvent in Handelinge 15 wys op die teendeel. Besluite van die ring het nie bindende gesag omdat dit die ring is wat dit besluit het nie. Dit het gesag omdat dit Skrifgebonde is of logies voortvloei uit gemeentes se gesamentlike Skrifgefundeerde

15 In die postmoderne konteks waarin al hoe meer gemeentes funksioneer, word baie verdra ter wille van beter samewerking en is daar "groter gemak met chaos, minder beheer... Baie meer selfstandigheid word geduld - by lidmate en gemeentes" (Niemandt 2007:21). Die kerk word ook baie meer gesien as 'n lewende organisme wat gedryf word deur verhoudings.

16 Volgens artikel 20 van die Kerkorde van die Nederduitse Gereformeerde Kerk het die kerkraad, ring, sinode en Algemene Sinode, elkeen na sy eie aard, 'n kerklike gesag wat deur Christus aan hulle verleen is. Die gesag van die ring oor die kerkraad is dieselfde as dié van die sinode oor die ring en van die Algemene Sinode oor die sinode (Die Kerkorde 2007:11). Jonker (1965:10,12) sê in hierdie verband dat Jesus Christus sy gemeente deur sy Woord regeer. Christusgesag is dus Woordgesag (Strauss 2010:3). 
roeping ${ }^{17}$. Gemeentes wat werklik besorg is oor mekaar se welsyn en roeping, sal nie gesamentlike besluite neem wat enige gemeente tot nadeel strek nie. Dit sou on-Skriftuurlik wees.

- Die ring is 'n uitstekende instrument waardeur gemeentes mekaar beter kan leer ken. Hier word nie net enkele afgevaardigdes op ringsittings bedoel nie, maar 'n werkswyse waar groter getalle lidmate meer betrokke is by die wel en weë van buurgemeentes. Afgevaardigdes na ringsittings is wel belangrik wanneer besluite geneem word, maar niks verhinder ringe om geleenthede te skep waar meer lidmate uit gemeentes saamvergader om mekaar te help om oplossings te kry vir probleme nie.

- In veral stedelike situasies kan die ring baie doen om buurgemeentes te help om hulle eie karakter te ontwikkel, in plaas van om elkeen alles vir almal te probeer wees. Waar byvoorbeeld ' $n$ meer tradisionele gemeente in harmonie met' $n$ meer vernuwende gemeente langs mekaar leef en mekaar hartlik ondersteun, kan "kompetisie" uitgeskakel word. Ontluikende kerke en gevestigde gemeentes kan onder mekaar se sorg binne ringsverband, as 'n eenheid God se Koninkryk in hulle omgewing dien.

- Die ring is ook 'n handige instrument om samewerking tussen gemeentes te bevorder. Waar byvoorbeeld die aantal dooplidmate in die gemeentes min is, kan die ring gesamentlike belydeniskampe of jeugprojekte reël. Gemeentes kan mekaar met funksies help, byvoorbeeld waar ' $n$ gemeente die pannekoektafel vir 'n klein buurgemeente beman tydens laasgenoemde se basaar. Op die platteland kan die ring byvoorbeeld ' $n$ konferensie reël oor 'n aktuele saak soos grondhervorming met die doel om mekaar aan moontlike oplossings te help.

- In denominasies of ringe waar opgeleide, voltydse predikante skaars is, kan gesonde ringe meehelp dat gemeentes predikante deel, of die verantwoordelikheid aanvaar om 'n opgeleide predikant af te sonder of aan te stel om ouderlinge van verskeie gemeentes op 'n deurlopende basis op te lei en toe te rus om die Woord in hulle onderskeie gemeentes te bedien. Die bedoeling mag nooit iets soos 'n biskop wees nie, maar eerder 'n "toeruster-van-toerusters" wat die gemeentes met sy gawes dien.

17 Meerdere vergaderings "tree op hulle eie terreine almal op in die Naam van Christus, sodat die Woord en nie 'n volgende meerdere vergadering nie, daarin die laaste sê moet hê" (Strauss 2010:11). 


\section{OP WEG NA BETER KERK}

In 'n tydsgewrig waar ortodoksie onder geweldige druk verkeer en ortopraksis byna verhef word tot dié merkteken van die ware kerk (vgl. Diversiteitsforum s.a.), kan die ring gemeentes met beide help. Enersyds is onderskeiding nodig tussen kernsake van die geloof waaroor niemand mag verskil nie en randsake (vgl. Celliers 2003:237). Andersyds staan 'n nabinne gekeerdheid in die pad van missionale kerkwees (vgl. Niemandt 2007:147evv). Soos wat die ring in die sestiende eeu in die lewe geroep is om die gemeentes te help met hulle nood om die regte belydenis, is die ring vandag reeds in plek om gemeentes te help in hulle nood om die regte belydenis, én in hulle nood om die uitleef van hulle roeping om missionaal kerk te wees. Beide is immers twee kante van dieselfde saak.

\section{BIBLIOGRAFIE}

Biesterveld, P. \& Kuyper, H.H.

1905. Kerkelijk handboekje bevattende de bepalinge der Nederlandsche Synoden en ander stukken van beteekenis voor de regeering der kerken. Kampen: Bos

Boumman, $\mathrm{H}$.

1934. Gereformeerd kerkrecht II. Kampen: Kok

BROWN, R.E.

1966. The gospel according to John. Volume 2. London: Chapman. The Anchor Bible.

Celliers, A.

2003. Skrifen Kerkorde. Enkele konstantes vanuit'n veelkantige beeld. Bloemfontein: UV (ongepubliseerde DTh-proefskrif).

Coertzen, P.

1984. Die Ring. Sy samestelling en werksaamhede. Kaapstad: N.G. KerkUitgewers.

DE JONG, O.J.

1980. Geschiedenis der kerk. Tiende druk. Nijkerk: Callenbach.

De VILLIERS, J.L.

1983. Die handelinge van die apostels. Deel 2. Kaapstad: N.G. Kerk-Uitgewers.

Die Kerkorde van die Nederduitse Gereformeerde Kerk.

2007. Met reglemente, kerkordelike riglyne en funksionele besluite soos vasgestel deur die Algemene Sinode in Junie 2007. Wellington: Bybel-Media

DIVERSITEITSFORUM.

s.a. [Aanlyn.] Bekom van: http://www.ngkerk.org.za./AS/diversiteitsforum.asp [2010, 11 Oktober] 
DunN, J.D.G.

1977. Unity and diversity in the New Testament. London: SCM.

1996. The acts of the apostles. London: Epworth.

Du ToIt, A.B.

1984. Oriënterende opmerkings oor die Pauliniese briefliteratuur. In: A.B. du Toit (red.), Handleiding by die Nuwe Testament $V$. Die Pauliniese briewe: inleiding en teologie. (Pretoria: N.G. Boekhandel), pp. 1-22.

Du ToIT, P.R.

1991. Die ring en effektiewe kerkvisitasie. In: P.J. Strauss (red.), Byderwets en gereformeerd. Kerkregtelike opstelle opgedra aan P.B. van der Watt. (Bloemfontein: Pro Christo), pp. 129-143.

FLEMING, H.C.J.

1961. Kerklike visitatore vir die Ned. Geref. Kerk. Die Kerkbode 20 September, pp. 446-449.

FLOOR, L.

1995. Efeziërs. Eén in Christus. Derde serie. Kampen: Kok. CNT.

GuTHRIE, D.

1981. New Testament Theology. Leicester: Inter-Varsity.

Handelinge Van Die Gekombineerde Kerkvergadering

s.a. HANDELINGE VAN DIE GEKOMBINEERDE KERKVERGADERING aan Cabo de Goeie Hoop van het jaar 1745-59. K.K.A. S1/A.

HEYNS, J.A.

1977. Die kerk. Pretoria: N.G. Kerkboekhandel.

JEREMIAS, J.

1971. New Testament theology. London: SCM.

JONKER, W.D.

1965. Om die regering van Christus in sy kerk. Pretoria: Unisa.

KLEYNHANS, E.P.J.

1973. Die kerkregtelike ontwikkelinge van die Nederduitse Gereformeerde Kerk in Suid-Afrika 1795-1962. Bloemfontein: s.n.

1985. Gereformeerde Kerkreg. Deel 3. Pretoria: N.G. Kerkboekhandel.

NAUTA, D.

1971. Verklaring van de kerkorde van de Gereformeerde Kerken in Nederland. Kampen: Kok.

Ned Geref Kerk.

1966. Handelinge van die Algemene Sinode van die Nederduitse Gereformeerde Kerk, pp. 563. 
1970. Handelinge van die Algemene Sinode van die Nederduitse Gereformeerde Kerk, pp. 700, 840.

Ned Geref Kerk Noord-KaApland.

1983. Handelinge van die Sinode van die Nederduitse Gereformeerde Kerk in Noord-Kaapland, pp. 565.

NiEmandT, N.

2007. Nuwe drome vir nuwe werklikhede. Geloofsgemeenskappe in pas met 'n postmoderne wêreld. Wellington: Lux Verbi.BM.

Niemandt, C.J.P.

2008. Ontluikende kerke - 'n nuwe missionêre beweging. Deel 2. Kernpraktyke van ontluikende missionêre kerke. Verbum et Ecclesia 29(1):139-162.

Pienaar, A.

2010. Anton Pienaar op die kerk se trappe. Kerkbode 1 Oktober, pp. 8.

PONT, A.D.

1991. Die historiese agtergronde van ons kerklike reg. Deel 2. Pretoria: Kital.

POP, F.J.

1980. De tweede brief van Paulus aan de Corintiërs. Nijkerk: Callenbach. PNT.

ROBERTS, J.H.

1983. Die brief aan die Efesiërs. Kaapstad: N.G. Kerk-Uitgewers.

SCHNACKENBURG, R.

1974. The church in the New Testament. London: Burns \& Oates.

Spoelstra, B.

1989. Gereformeerde kerkreg en kerkregering. 'n Handboek by die kerkorde. Hammanskraal: Teologiese skool.

Strauss, P.J.

2010. Kerk en orde vandag. Met die klem op die NG Kerk. Bloemfontein: Sun Media.

SWEET, L.

2007. Bestorm die perfekte storm. In: S. Joubert (red.), Die perfekte storm. Hoe die gelowige van vandag die wêreld van môre kan oorleef. (Vereeniging: Cum), pp. 15-44.

VAN ZYL, H.C.

1989. 'n Redaksie-historiese lesing van Handelinge 15:1-35. Acta Theologica 9(1):43-61.

VORSTER, J.D.

1981. Die kerkregtelike ontwikkeling van die Kaapse kerk onder die kompanjie 1652-1795. Tweede uitgawe. Kaapstad: N.G. Kerk-Uitgewers. 
Acta Theologica

Trefwoorde

Kerkreg

Ring

Klassis

Kerkverband

Kerkeenheid
Keywords

Church polity

Presbytery

Classis

Denomination

Church unity 